\title{
The Trophic Cocktail Made by Chromaffin Cells
}

\author{
K. Unsicker, S. Bieger, "D. Blottner, ${ }^{* *}$ K. Flanders, D. Gehrke, C. Grothe, A. Henkel, M. Hüll, V. \\ Meyer, P. Oquendo, D. Otto, F. Stögbauer and R. Westermann \\ Departments of Anatomy and Cell Biology, University of Marburg, "Department of Anatomy, \\ Free University of Berlin, Germany and "Laboratory of Chemoprevention, \\ NIH, NCI, Bethesda, MD 20892, USA
}

We studied the molecular composition of the neurotrophic/growth factor cocktail synthesized, stored and liberated by adrenomedullary chromaffin cells. Chromaffin cells have a dual capacity as models of the neuronal biochemical machinery and as therapeutic tools (implants) in several neural disorders, most notably Parkinson's disease. Cultured bovine chromaffin cells release a proteinaceous material into their culture medium that, when applied to a wide range of different embryonic neurons from the CNS and PNS in vitro, promotes their viability and neuritic growth /1-3/. Stimulation of the chromaffin cells with cholinergic agonists or high $\mathrm{K}^{+}$enhances the amounts of the trophic material (addressing ciliary and dorsal root ganglionic neurons) in parallel with the amounts of catecholamines and chromogranin A, suggesting an exocytotic mode of release.

Molecular analysis of identified/novel growth factors in the adrenal medulla/chromaffin cells using conventional biochemical fractionation techniques, Western and Northern blots, and immunocytochemistry revealed FGF-2 /4/, TGF$\beta$ s, a CNTF-like $22 \mathrm{~K}$ moiety, and a potentially novel approx. $13 \mathrm{kDa}$ molecule with a trophic capacity resembling CNTF as constituents. FGF2 was localized to the secretory granules of chromaffin cells by immunoelectronmicroscopy, and highly enriched chromaffin granules revealed a predominant $46 \mathrm{kDa}$ immunoreactive form of FGF-2 /5/. FGF-2 (18 kDa) was liberated from cultured bovine adrenomedullary cells in the absence of exogenous secretagogues. However, an exocytotic mode of release of any immunoreactive form of FGF-2 has not yet been demonstrated. Despite the presence of intense immunoreactivities for TGF- $\beta$ s 1,2 and 3 in chromaffin cells, their mRNAs were barely detectable. Chromogranin A isolated by immunoaffinity chromatography had trophic activity for sensory neurons. However, transfection of its gene into mammalian cell lines resulted in a chromogranin A product lacking a trophic function. Together with data documented by other groups concerning the presence of IGFs, ILs and other growth factors in the adrenal medulla, our results demonstrate the wide range of trophic molecules in this paraneuronal organ.

Two of the trophic molecules contained in chromaffin cells have been tested for their capacity to ameliorate the destructive consequences of neurotrauma and -degeneration. In a mouse MPTP-model of Parkinson's disease FGF-2 applied in gel foam unilaterally to the right striatum restored tyrosine hydroxylase activity, and dopamine and dopamine-related striatal transmitter systems bilaterally, when the FGF-treatment started simultaneously with or shortly after the administration of MPTP /6,7/. After a delay of seven days, however, FGF was no longer effective. Autoradiographic studies revealed a very limited penetration of ${ }^{125}$ I-FGF2 away from the gel foam into the striatum, suggesting that the observed bilateral effects were largely indirect and required other molecular mediators. Since a high CNTF-like neurotrophic activity could be eluted from the gel foam, which was not blockable by anti-FGF-2 antibodies, the hypothesis was tested that CNTF was the protective agent for MPTP-lesioned nigrostriatal neurons and was induced by FGF-2. However, CNTF applied instead of FGF-2 locally to the striatum in MPTP-treated mice was not effective.

FGF-2, CNTF and TGF- $\beta$ s were also tested for their capacity to prevent the death of preganglionic spinal cord neurons in the inter- 
mediolateral column, which innervates the adrenal medulla, after a unilateral adrenomedullectomy in adult rats. FGF-2, CNTF and TGF- $\beta 2$, but not TGF- $\beta 1$, rescued the spinal cord neurons after local application to the medullectomized adrenal gland $/ 4,8,9 /$.

Our data suggest that chromaffin cells synthesize, store and liberate a variety of growth factors with a neurotrophic capacity, some of which still have to be identified at a molecular level. Chromaffin cell-derived neurotrophic molecules may be of importance for the maintenance of the preganglionic efferent and sensory afferent innervation of the adrenal medulla. These proteins, however, are probably also responsible for the beneficial effects of chromaffin cell transplants in animal models of neurodegenerative diseases.

Supported by grants from the German Research Foundation.

\section{REFERENCES}

1. Unsicker K, Blottner D, Gehrke D, Grothe C, Heymann D, Stögbauer F, Westermann R. Neuroectodermal cells: storage and release of growth factors. In: Gorio A et al. (eds.), NATO ASI Series, Neural Development and Regeneration Vol. H22. Berlin/
Heidelberg: Springer-Verlag, 1988; pp. 43-55.

2. Unsicker K, Blottner D, Gehrke D, Grothe C, Lehr A, Stögbauer F, Westermann $R$. Molecules involved in trophic neuron-neuron interaction. In: Björklund $A$ Aguayo AJ, Ottoson D (eds.), Brain Repair, Proceedings of an International Symposium at the WennerGren Center, Stockholm, 24-27 May 1989, M. Stockton Press.

3. Unsicker K, Blottner D, Gehrke D, Grothe C, Heymann D, Stögbauer F, Westermann R. Characterization of trophic factors stored and secreted by neurons. In: Lauder JM (ed.), Molecular Aspects of Development and Aging of the Nervous System. New York: Plenum Press, 1990; pp. 63-73.

4. Blottner D, Westermann $R$, Grothe $C$, Böhlen $P$, Unsicker $\mathrm{K}$. Basic fibroblast growth factor in the adrenal gland. Eur J Neurosci 1989; 1: 471-478.

5. Westermann R, Johannsen M, Unsicker K, Grothe C Basic fibroblast growth factor (bFGF) immunoreactivity is present in chromaffin granules. J Neurochem 1990; 55: 285-292.

6. Otto D, Unsicker K. Basic FGF reverses chemical and morphological deficits in the nigrostriatal system of MPTP-treated mice. J Neurosci 1990; 10: 1912-1921.

7. Otto D, Unsicker K. Basic FGF modulates dopamine and dopamine-related striatal transmitter in the intact and MPTP-lesioned mouse. 1992, submitted.

8. Blottner D, Brüggemann W, Unsicker K. Ciliary neurotrophic factor supports target-deprived preganglionic sympathetic spinal cord neurons. Neurosci Lett 1989; 105: 316-320.

9. Blottner D, Baumgarten $\mathrm{H}-\mathrm{G}$, Flanders K, Roberts AB, Sporn $M$, Unsicker $\mathrm{K}$. Target-deprived preganglionic sympathetic neurons in the spinal cord selectively marked by NADPH-diaphorase are rescued in vivo by TGF- $\beta 2$, but not TGR- $\beta 1$. 1992, submitted. 

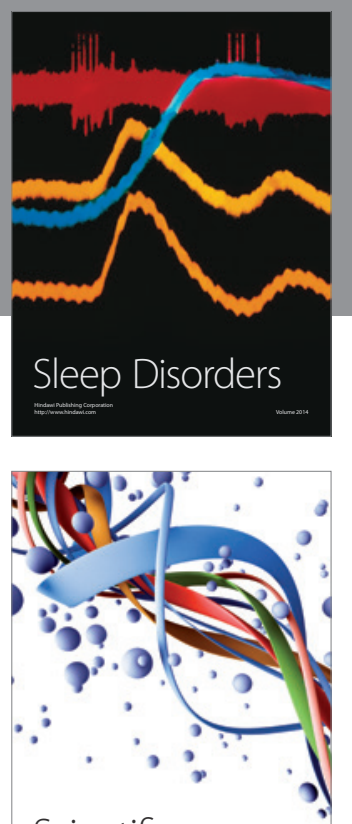

Scientifica
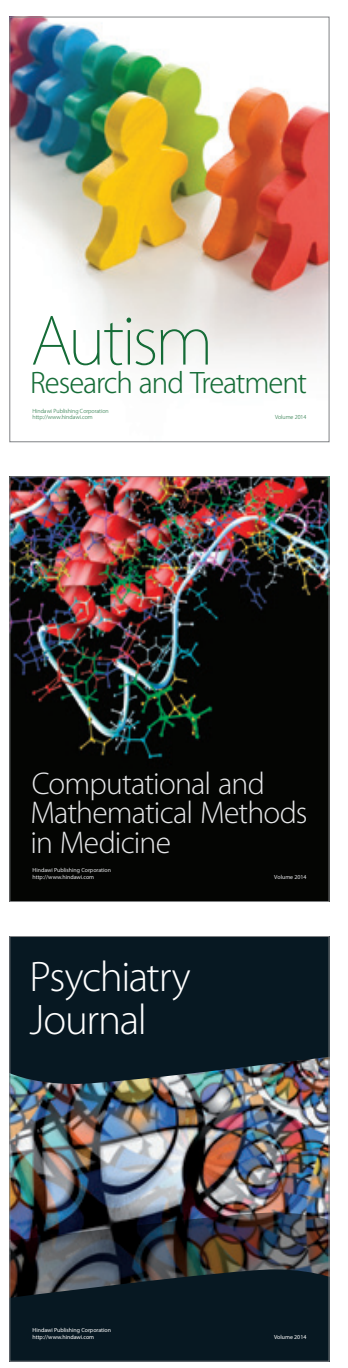
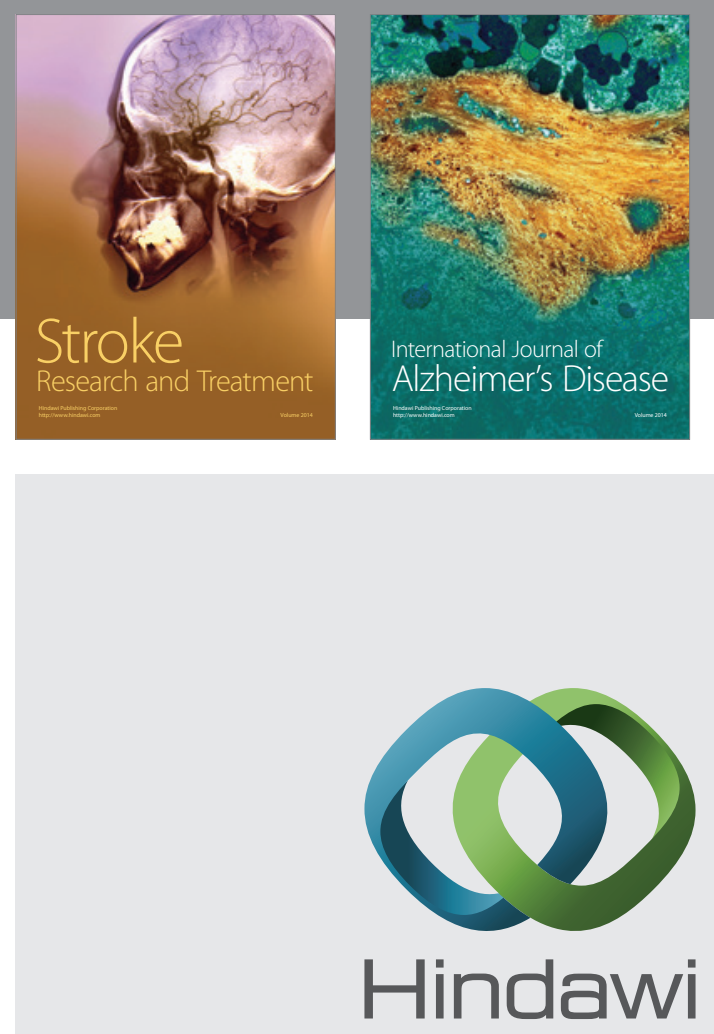

Submit your manuscripts at

http://www.hindawi.com
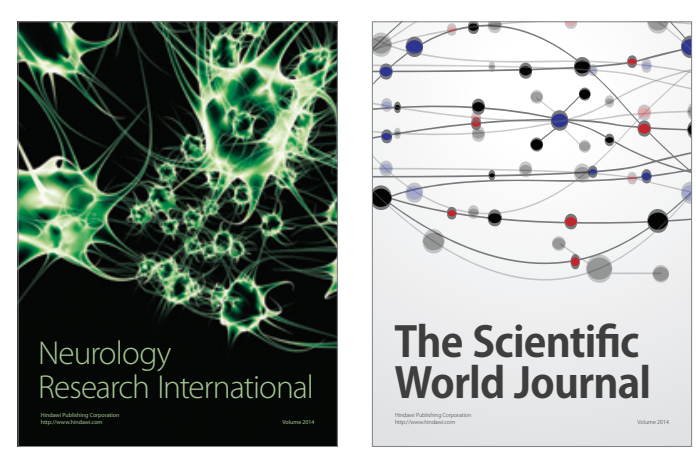

The Scientific World Journal

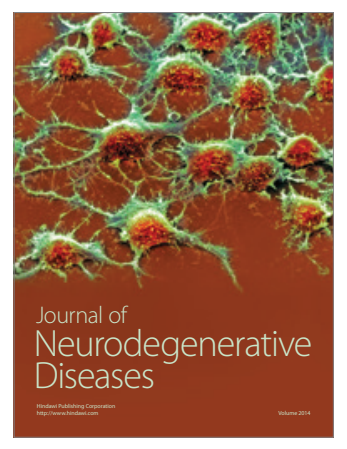

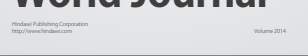

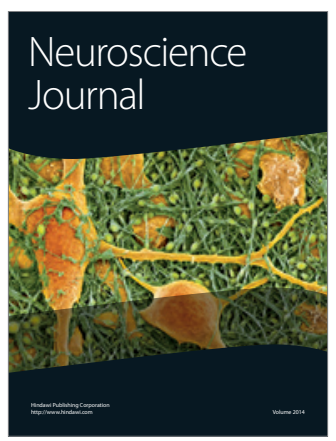

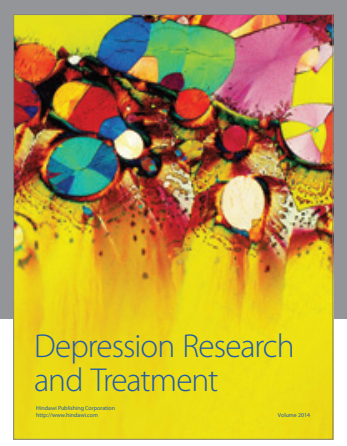
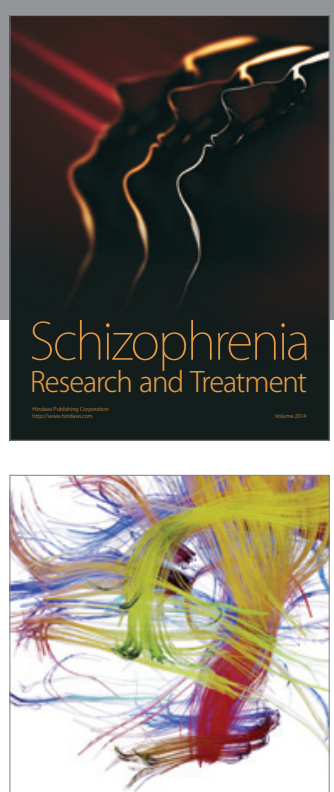

Brain Science

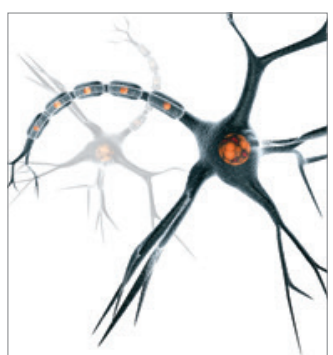

Neural Plasticity
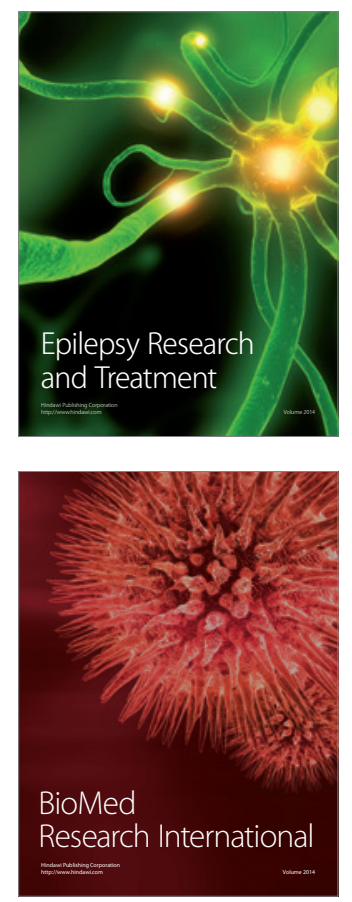

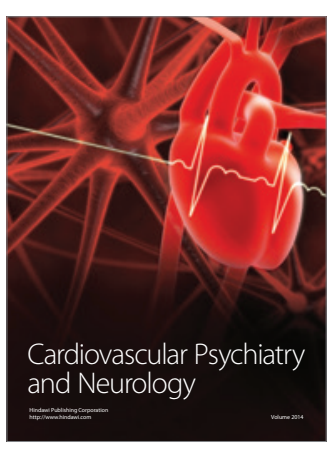

Parkinson's

Disease
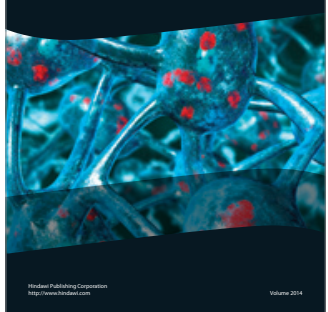